\title{
CONCEPTIONS OF SOUL IN OLD-ESTONIAN RELIGION.
}

\section{$\underline{\text { Tarmo Kulmar }}$}

The paper presents a comparative survey of the four theories on conceptions of soul in the OldEstonian religion, the authors of which are Oskar Loorits, Ivar Paulson, Uku Masing and Johann Matthias Eisen. The so-called Wundt- Arbman's theory serves as a basic theoretical starting-point for the comparison.

While the most important shortcoming of Sir Edward Tylor's theory of the soul was the unitarity of the soul (Tylor 1989, 210), a great step forward was taken by the representative of nationspsychology Wilhelm Wundt who gave much attention to the point that the animistic soul was pluralistic. There are two main germs - the body-soul (Körperseele) and the free-soul (Freiseele). The former is connected with the organism, the latter is capable of departing from the body and returning to it (Wundt 1920, 79 etc.).

Wundt's theory of the pluralism of souls in archaic religions was developed further by Ernst Arbman. He noticed that the body-soul itself wasn't unitary, it could be devided in life-souls and the ego-soul. The former ones sustain physical, the latter one psychic functions. The second important addition is that in some cases the ego-soul can overtake the functions of the free-soul. It means that the free-soul can act as a body-soul which has taken the form outside the body (Arbman 1927, 166, 123).

This rather simplified scheme is mostly based on the research of the religions of Indo-European nations. But as we'll see hereafter, it is successfully applied to the Estonians as well. However, it obviously isn't universal as there exist also other kind of soul-phenomenologies suitable for religions of nations not having had close contacts with the Indo-Europeans.

\section{THE BODY-SOUL}

Loorits calls it the life-force (elujõud) which leaves the body when a human being dies. It is moving and acting in the body, it has a physical manner. It can also be called organ-soul and it is located in the heart, lungs, kidneys, genitals, blood, secretions, hair, nails, spittle and teeth. They are all known in the folklore as magic instruments, active (talismans) or passive (amulets) fetishes. The eye was an organ through which the soul could get out as a glance just to follow or to put an evil eye on the surroundings. The mouth was a place through which one's soul could exit and an alien soul could enter (Loorits 1949, 47-64). Treating the power-centres as a unified organ-soul is a contact area for both Loorits and Wundt. But an important difference is that Loorits considers the ego, shadow, double, figure, name to be the other component of the body-soul. One's double follows oneself as a shadow; ego is connected with the word character which reflects the nature of a person; under the word shadow a protector is meant, the soul of a dead person lived on as a shadow; figure also serves as an analogue to the shadow-soul (Loorits 1949:153-218). The name was an attribute of individuality connected with a great amount of taboos. All in all the ego formed an ego-soul. 


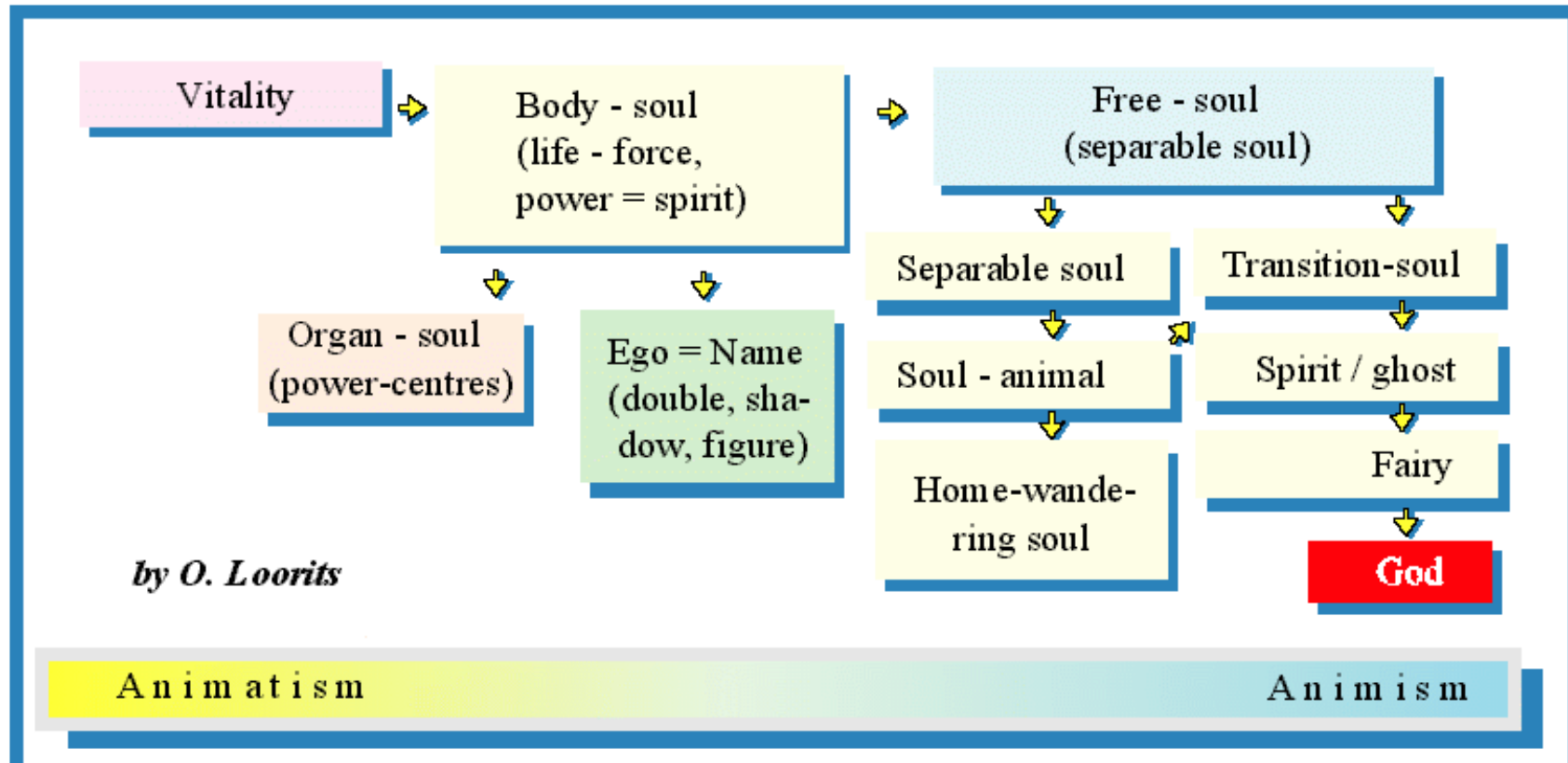

Fig. 1. Soul - phenom enological scheme of Old - Estonian Religion

Paulson, refering to the body-soul also by the name life-souls (eluhinged), specifies (relying on Arbman) that the body-soul isn't unitary, there's a plenty of them. The structure of the ego-soul by Paulson is similar to that of Loorits's, but he declares (relying on Arbman again) that the ego-soul can take over the functions of the free-soul as a breath-soul, and it can leave the body as a soulanimal or as a dream. He has also got a connecting between the free-soul and the body-soul - a king of soul of life (eluvaim), the mind (meel) (Paulson 1958:208, 234, 253-263).

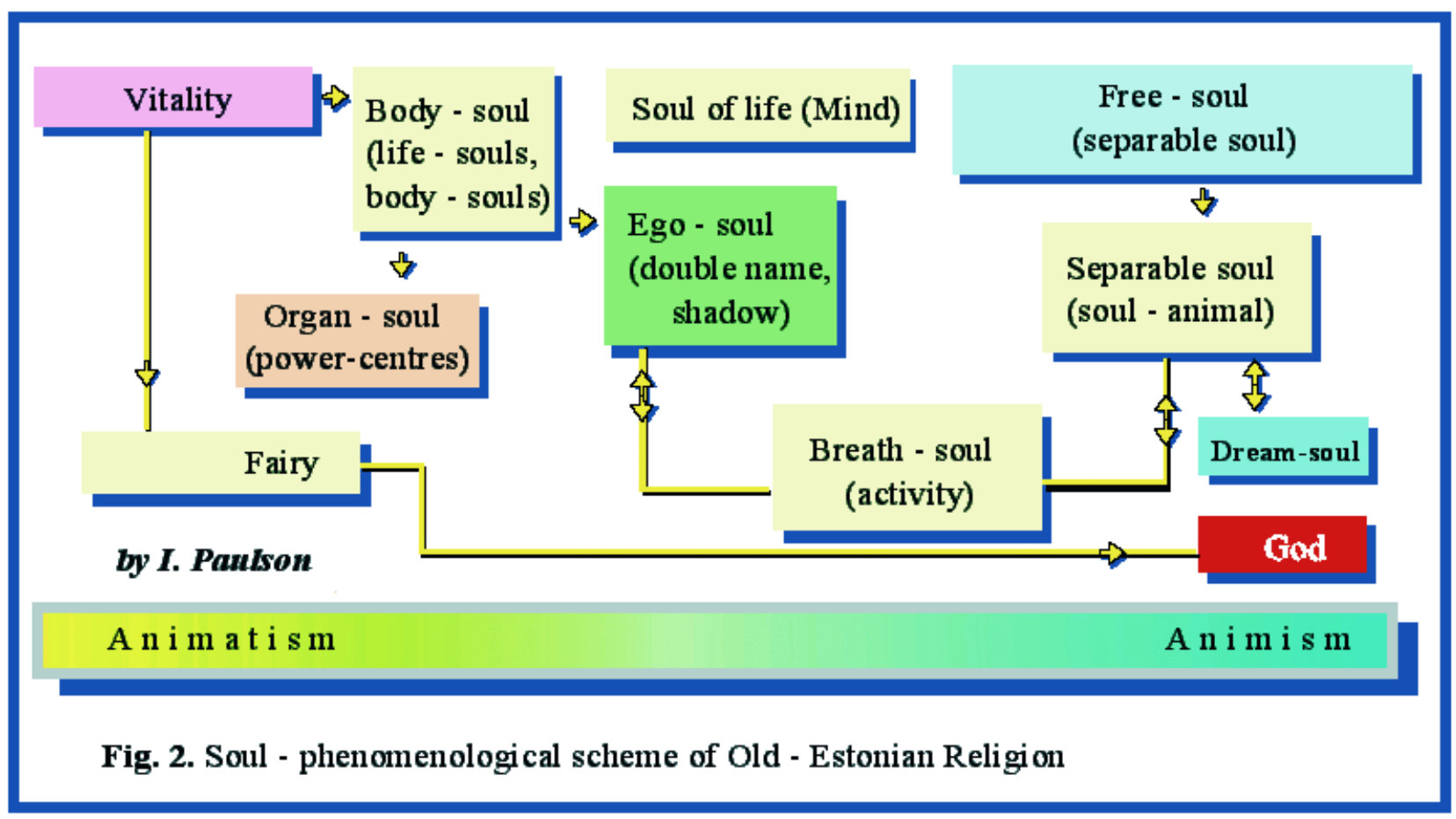

Masing treats organs as the centres of power and calls them a soul of life. So in his conception the bodysoul is unified, but as a soul of life it is divided between different organs. Self, shadow and double he 
treats as a breath-soul which is a kind of link between the body-soul and the free-soul (real-soul pärishing). The breath-soul is also connected with Masing's understanding of preani-mism: in the animatistic period people saw not the living corpse but the double of the deceased, his shadow. When animism developed further that shadow, which could also turn into the nature-spirit, acquired the meaning of the breath - soul in the composition of the body-soul (Masing s. a., 69-93).

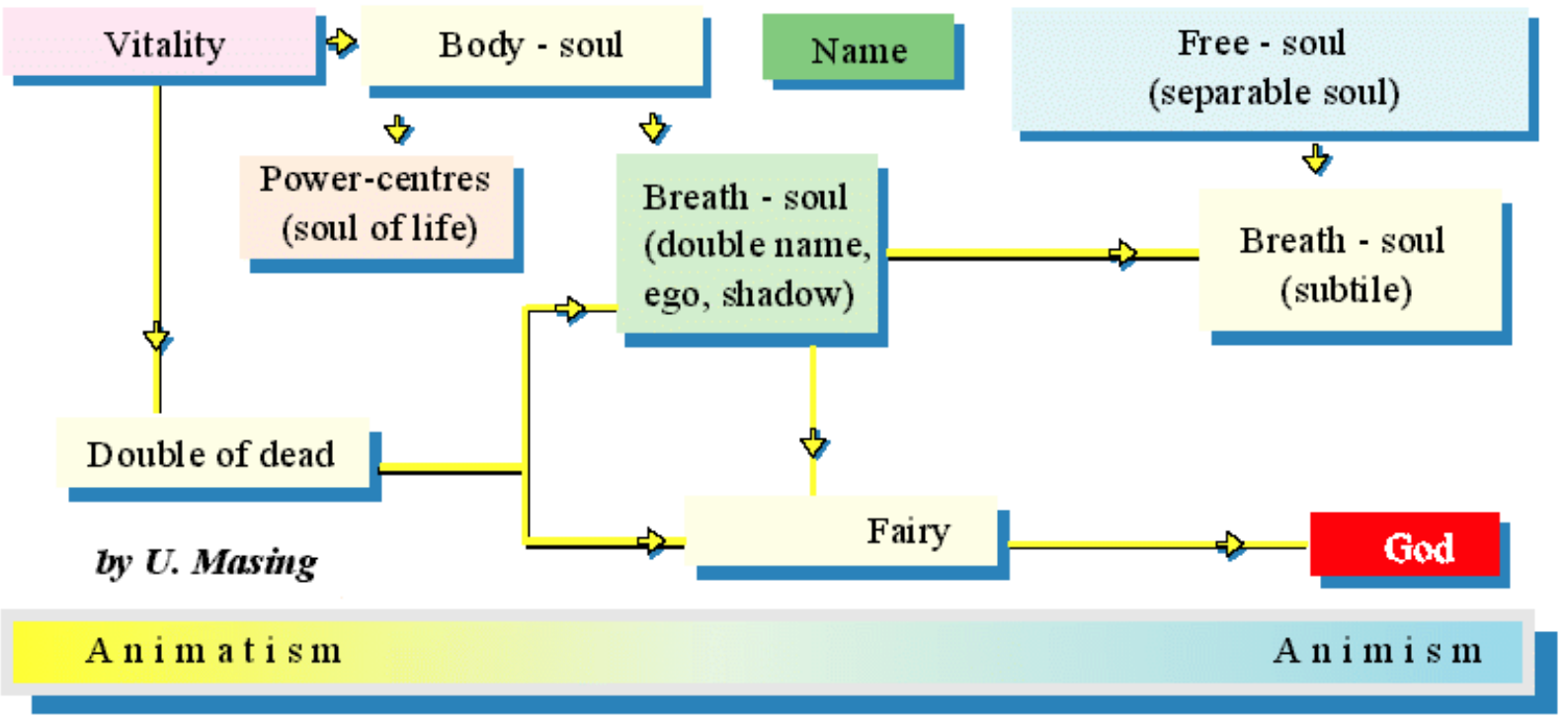

Fig. 3. Soul - phenomenological scheme of Old - Estonian Religion

Eisen acted rather as a collector of folkloristic material than a creator of theories. However, he was asquainted with contemporary studies and his books make it clear that he distinguished the body-soul and power-centres in it. The latter ones are connected with the free-soul which could leave the body as a soul-animal and appear in dreams (Eisen 1926:112, 120, 123, 254).

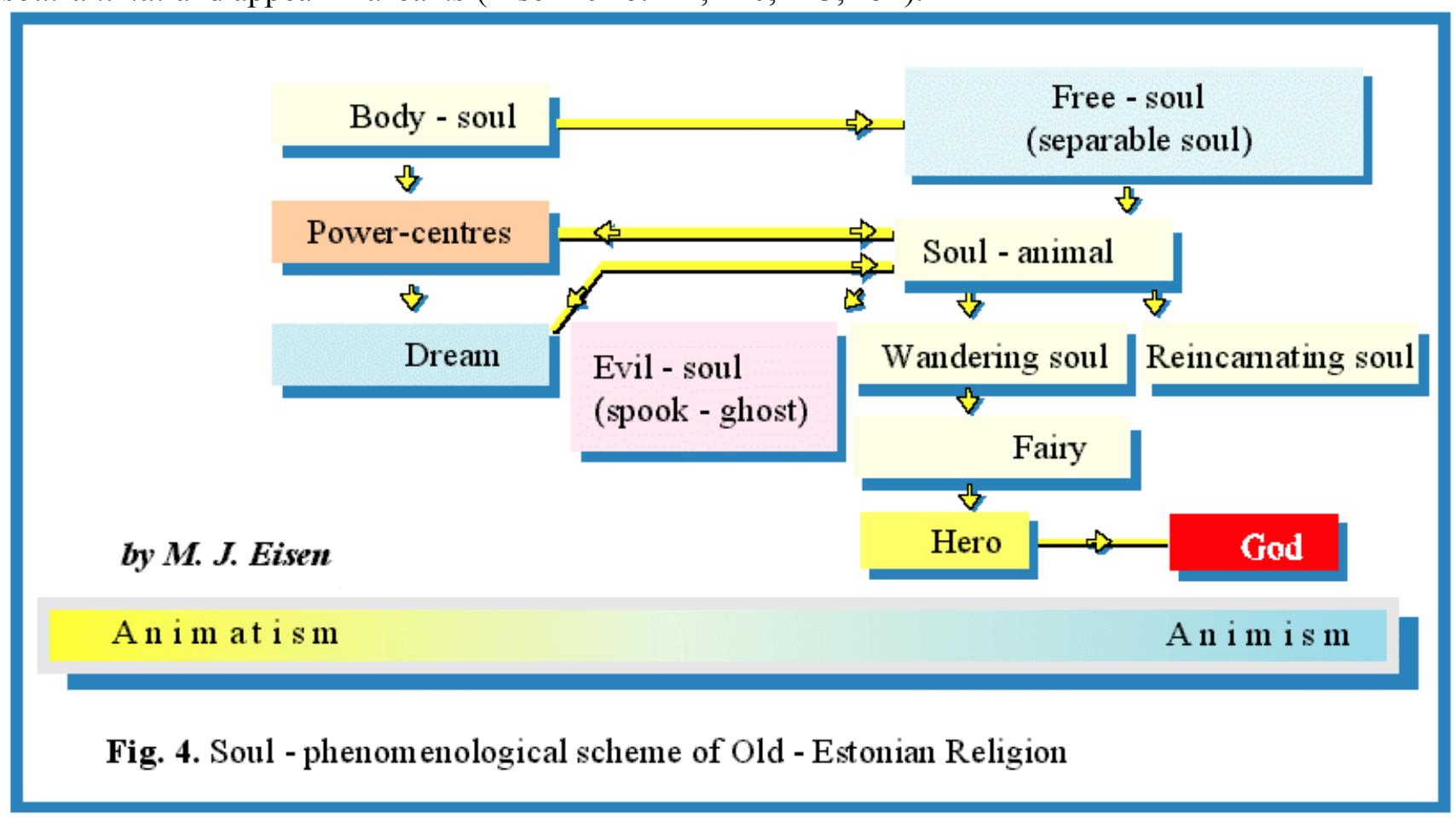




\section{THE FREE-SOUL}

Loorits calls the free-soul generally with the term separable-soul (irdhing). More particularly the separable-soul is an earlier stage of the free-soul - a soul that can on some occasion leave the body for a while. It leaves the body as a soul-animal (insect, butterfly, bird, mouse, snake). Soul of a dead person that leaves the body as a soul-animal may appear as spook-ghost (home-wandering soul - kodukäija, mardus). The second and later stage of the free-soul is the transition-soul (siirdhing), which transists to enliven a new body. It can appear as a insect, bird, snake. Worship of snakes can be observed as far back as the Finno-Permian era so the archaeological data permits to place the belief into transition-soul into Early-Neolithic or even Late-Mesolithic era (Loorits 1949:289-365).

Paulson, making no distinction between separable- and transition-soul, states that the main feature of the free-soul is its appearance outside the human body and its relative autonomy in relations with the body. Free-soul as a separable-soul can appear as a soul-animal as well as a dream-soul. In some occasion even the ego-soul belonging to the body-soul and acting as an active breath-soul can be a separable soul. So the separable-soul can act both as itself as well as ego-soul in body-soul (Paulson 1958:267-277).

Masing treats the separable-soul as a special subtile form of a breath-soul. As we saw above, by Masing, the earlier stage of the breath-soul (Ego, shadow, double) belonged to the body-soul and was the same as the double of the dead. This subtile breath-soul really means an ego-soul that leaves the body after the death and becomes a nature-spirit, fairy (Masing 1996, 95-97).

Eisen also distinguishes the free-soul, but he called it the dead person's soul (surnuhing) which leaves the body in the form of a soul-animal. So the body-soul reviving the power-centres becomes a dead-person's soul. The latter is divided in three:

1. souls of evil persons and witches (evil-souls - kurihinged); they become haunting ghosts.

2. wandering ghosts who for some reason can't find their peace (wandering souls -rändhinged).

3. souls who have found their peace and come home to eat only in autumnal souls' visiting time (reincarnating souls - ümbersündivad hinged) (Eisen 1897, 22).

After having a brief research upon different conceptions by different authors who have studied soulphenomenology of Old-Estonian religion, we can see that although schematically their approaches differ to certain extent, they all agree upon the division of the soul into two parts - the body-soul and the free-soul. That way we have got a confirmation to the hypothesis that in order to study the soul-phenomenology of Old-Estonian religion, the Wundt-Arbman's basic theory should be applied.

To comment upon the comparative scheme given on the next page we should explain the development of the concepts of the fairy/tutelary spirit and the god. Loorits states (proceeding from the fact the word fairy in Estonian - haldjas - is a loan from Germanic languages) that from the transition-soul the idea of a nature-spirit, later on an anthropomorphic fairy and polytheistic god developed. The appearance of the anthropomorphic fairy can really be considered to have taken place in the end of the Late-Neolithic or in the Early-Metal-Age (using the data of archaeological excavations). But the appearance of the nature-spirits should be placed into earlier times. At least Paulson does when stating that teriomorphic nature-spirit could most likely to be met in the earlier stage of animism. Paulson, however, doesn't make clear - when did fairies in the human beings make their appearance. Gods also developed from the nature-spirit. Masing, as we could see above, stated that the fairy originated from the double of the dead person but later also from the breath-soul 
of the dead person: the former image was meant to rule in the animatistic stage, the latter one in the animistic period. Eisen's point of view is quite similar to that of Loorits's. Eisen however has an intermediate level between the fairy (nature-spirit) and the god - the hero.

It is obviously too premature to guess which of these soul-conceptions is proved correct. Eisen's scheme, unfortunately, has been left unfinished. The scheme by Masing seems to be a bit too constructed; the one by Loorits is rather perfect but partly outdated. Paulson's scheme is developed further but it seems that he has left out something important refered to by Loorits. But here it is important to state that the soul-phenomenology of Old-Estonian religion is mostly characterised by the Indo-European soul-scheme. The reasons for that phenomenon are obviously long-lasting and important relations with Indo European nations in prehistoric times (the Proto-European substratum culture of Kunda during the Mesolithic Age; the string-pottery-culture in the Late Neolithic; constant relations with the Baltic, Scandinavian and German tribes in the Early-Metal-Age and during all periods of the Iron-Age).

Translated by Ivar Vaikmäe

\section{References}

Arbman, Ernst 1927. Untersuchungen zur primitiven Seelenvorstellung mit besonder Rücksicht auf Indien. I. Le Monde Oriental, no. 20. Uppsala.

Eisen, Matthias Johann1897. Kodukäijad. Narva.

Eisen, Matthias Johann 1926. Eesti vana usk. Eesti Kirjanduse Seltsi Toimetised nr. 21. Tartu. Loorits, Oskar 1949. Grunzüge des estnischen Volksglaubens. I. Uppsala-Köpenhamn.

Masing, Uku 1996. Eesti usund. Tartu.

Paulson, Ivar 1958. Die primitiven Seelenvorstellungen der nordeurasischen Völker. The

Etnographical Museum of Sweden. Monographic Series. no. 5. Stockholm.

Tylor, Edward 1989. Prevobotnaja kul'tura. Moskva.

Wundt, Wilhelm 1920. Völkerpsychologie. IV. Band: Mythus und Religion, I. Teil. Leipzig. 